\title{
MÍNIMO EXISTENCIAL, ASSISTÊNCIA SOCIAL E ESTADO DE DIREITO - ANÁLISE DE DECISÃO PROFERIDA PELO TRIBUNAL CONSTITUCIONAL FEDERAL DA ALEMANHA ${ }^{1}$
}

\section{EXISTENTLAL MINIMUM, SOCLAL ASSISTANCE AND RULE OF LAW - ANALYSIS OF A DECISION BY THE FEDERAL CONSTITUTIONAL COURT OF GERMANY}

Ingo Wolfgang Sarlet ${ }^{2}$

Eduardo Luís Kronbauer ${ }^{3}$

Recebido em: 05/04/2021 Aceito em: 21/07/2021

iwsarlet@gmail.com eduardo.kronbauer@yahoo.com.br
Resumo: O presente artigo trata de análise de decisão proferida pelo Tribunal Constitucional Federal da Alemanha acerca da legitimidade constitucional de reforma legislativa do sistema de seguridade social, conhecida como legislação Hartz-IV. Em relação à metodologia aplicada, o artigo utiliza o método de estudo de caso jurisprudencial. Os comentários direcionados ao caso analisado tomam como base a legislação estrangeira vinculada à decisão, bem como a revisão de bibliografia nacional e estrangeira. Assim, a análise parte da perspectiva da necessidade de garantia, pelo Poder Judiciário, da eficácia de preceitos fundamentais como a dignidade da pessoa humana e o mínimo existencial, sem que, para isso, sejam violados os princípios do Estado de Direito e, em especial, o da separação dos poderes. Apresenta-se, na primeira parte, uma breve conceituação destes preceitos constitucionais para, na segunda parte, analisar-se a legislação objeto do julgamento em tela bem como os fundamentos da decisão considerados mais relevantes, com a finalidade de, ao fim, demonstrar como o Tribunal Constitucional Federal, ao considerar inconstitucional a legislação, procurou se manter no âmbito das suas funções definidas constitucionalmente, na medida em que, ao invés de atuar como legislador positivo, apenas tratou de reconhecer que a legislação não estava de acordo com o mínimo existencial, sem definir, contudo, novos termos à legislação, deixando tal tarefa a cargo do legislador infraconstitucional.

Palavras-chave: Tribunal Constitucional Federal; mínimo existencial; Estado de Direito; separação dos poderes.

\begin{abstract}
This paper aims to analyze a ruling of the Federal Constitutional Court of Germany concerning the constitutional legitimacy of some aspects of the legislative reform of the social security system (known as Hartz-IV legislation). The analysis starts from the perspective of ensuring the effectiveness of fundamental rights such as the dignity of the human person and the existential minimum without violating for this purpose the Rule of law and the separation of powers. In the first part, a brief conceptualization of these constitutional precepts is presented. In the second part, the legislation that is the object of the judgment is analyzed, as well as the considered most relevant reasonings and arguments of the decision, in order to demonstrate how the Federal Constitutional Court, by considering the legislation unconstitutional, sought to remain within its constitutionally defined functions, since, instead of acting as a positive legislator, only recognized that the legislation was not in accordance with the existential minimum (and with the Fundamental Law of Germany), without defining new terms to this legislation, leaving this task to the infra-constitutional legislator.
\end{abstract}

Keywords: Federal Constitutional Court; Existential minimum; Democracy; Rule of Law; Separation of powers

\footnotetext{
1 BVerfGE, Urteil des Ersten Senats vom 09. Februar 2010 - 1 BvL 1/09 -, Rn. 1-220, Disponível em: http://www.bverfg.de/e/ls20100209_1bvl000109.html (acesso em 18.08.2020).

2 Pontifícia Universidade Católica do Rio Grande do Sul. Rio Grande do Sul. Brasil.

${ }^{3}$ Albert-Ludwigs-Univeristät Freiburg. Alemanha.
} 


\section{INTRODUÇÃO}

O presente artigo trata da análise, mediante recurso ao método de estudo de caso jurisprudencial, da decisão proferida pelo Tribunal Constitucional Federal alemão (Bundesverfassungsgericht - BVerfGE) - TCF, o qual, sob a perspectiva do mínimo existencial, analisou a constitucionalidade das disposições contidas no $4^{0}$ Ato para Serviços Modernos no Mercado de Trabalho (Viertes Gesetz für moderne Dienstleistungen am Arbeitsmarkt) de 24 de dezembro de 2003 (Hartz IV), que abrange a assistência em virtude do desemprego (Arbeitslosenhilfe) e assistências e benefícios sociais de caráter geral, conforme definidos no Segundo Livro do Código Social (Sozialgesetzbuch Zweites Buch - SGB II). Ainda, no que diz respeito ao método utilizado, destaca-se que os comentários direcionados ao caso estudado tomam como base a Constituição e a legislação alemãs, bem como a revisão da bibliografia nacional e estrangeira sobre o tema, principalmente alemã.

A discussão teve origem em ação ajuizada por famílias beneficiárias do seguro sob o fundamento de que o valor recebido para fins de sustento de seus filhos menores de 14 anos (207 Euros) ${ }^{4}$ seria insuficiente para garantir sua subsistência, pelo que, haveria violação a preceitos fundamentais previstos na Lei Fundamental da Alemanha - LF, mais especificamente, à dignidade humana e ao mínimo existencial. ${ }^{5}$

Nesse sentido, o estudo do caso em questão tem a finalidade de verificar a forma pela qual o TCF tratou a matéria, em referência à concretização de preceitos constitucionais e à atribuição de eficácia a direitos fundamentais. Além do mais, a análise leva em consideração, ainda, questões que envolvem os princípios do Estado de Direito e da separação dos poderes, considerando o dever de harmonia entre os poderes e a limitação no exercício de suas funções.

Portanto, na primeira parte, o artigo foca na breve exposição dos conceitos que se entende mais relevantes ao caso. Serão abordados, desse modo a concepção e relevância do mínimo existencial, como preceito fundamental, bem como dos princípios do Estado de Direito e da separação dos poderes. Demonstrar-se-á que, ao garantir eficácia a um direito fundamental, o Tribunal Alemão não deixou de observar a importância da manutenção da ordem e da separação dos poderes, no sentido de respeitar os limites funcionais do Poder Judiciário.

$\mathrm{Na}$ segunda parte, apresentam-se os termos dispostos na legislação analisada no julgamento e os fundamentos mais importantes da decisão proferida pelo Tribunal Constitucional alemão para, subsequentemente, fazer-se uma análise destes sob a perspectiva dos preceitos acima mencionados. Destaca-se que a pretensão do artigo não é apenas enaltecer a eficácia dada a um direito fundamental pelo Tribunal, ao afastar dispositivos da legislação infraconstitucional que não estariam de acordo com esta garantia, mas de analisar como isto pode ser feito sem que, para tanto,

\footnotetext{
${ }^{4}$ BVerfG - BvL 1/09: Ab dem 1. Januar 2005 erhielten damit zur Bedarfsgemeinschaft gehörende Kinder bis zur Vollendung des 14. Lebensjahres in den alten Ländern einschließlich Berlin (Ost) zunächst 207 Euro (...) (parágrafo 22).

5 Importante referir que, não há prejuízos à presente análise pelo fato de a decisão ter sido proferida em 2010, na medida que a maior relevância está nos fundamentos que, atualmente, continuam a ser debatidos no âmbito do direito constitucional.
} 
Mínimo existencial, assistência social e estado de direito - análise de decisão proferida pelo Tribunal Constitucional Federal da Alemanha

isto impacte de modo desproporcional outros preceitos constitucionais, em especial o da separação dos poderes e os princípios basilares do Estado de Direito.

\section{CONCEITOS E PRINCÍPIOS ENVOLVIDOS NA QUESTÃO}

A finalidade do presente artigo, como visto, é de realizar a análise dos fundamentos da decisão do TCF, destacando alguns aspectos relevantes que resultaram na garantia de eficácia a um direito fundamental - o assim chamado direito a um mínimo para uma vida digna (mínimo existencial) - sem, com isso, violar o Estado Democrático de Direito, com destaque para a separação dos poderes. Entretanto, antes de adentrar a análise da decisão em tela, importante fazer uma breve exposição dos conceitos que servirão de base ao estudo do caso, mais especificamente, em relação ao Estado de Direito e, subsequentemente, ao princípio da separação dos poderes, bem como ao mínimo existencial.

\subsection{Estado de Direito e separação dos poderes}

O Estado de Direito tem como finalidade a garantia de um "ideal de juridicidade, de responsabilidade e de previsibilidade" (ÁVILA, 2012, p. 94). Ou seja, visa à garantia de estabilidade e de segurança nas relações jurídicas por meio, dentre outros, dos preceitos da legalidade, do devido processo legal, da separação dos poderes e da segurança jurídica (ÁVILA, 2012). Além do mais, caracteriza-se pela forma de ordem em que governantes e governados se sujeitam ao império da lei, sendo que o Estado, neste caso, deve agir secundum legem, e as relações de direito são orientadas pelo regime de direito. As relações jurídicas, desse modo, são conduzidas por critérios normativos com a finalidade de gerar estabilidade e justeza nestas relações (CARRAZZA, 2013, p. 436). Tratase, assim, o Estado de Direito, da garantia da ordem e do controle das relações sociais (FINNIS, 2011, p. 270-271) ${ }^{6}$, na medida em que estas devem estar sob o governo das leis, e não dos homens (FINNIS, 2011, p. 272). A ideia principal é a de que a forma do direito é capaz de estabelecer a racionalidade do uso do poder estatal, considerando que todo e qualquer poder é exercido em conformidade com sua "competência" (KRONBAUER, 2019). Isso significa que as práticas, inclusive do detentor do poder, são delimitadas por normas de forma estrita. Assim, torna-se possível "calcular" e prever a atividade que o Estado exercerá, conforme "a probabilidade de este se comportar segundo as normas jurídicas" (BARZOTTO, 2017, p. 81).

\footnotetext{
6 "The name commonly given to the state of affairs in which a legal system is legally in good shape is 'the Rule of Law' (capitalized simply to avoid confusion with a particular norm within a legal system). The Rule of Law, the specific virtue of legal systems, has been well analyzed by recent writers; so my discussion can be brief. A legal system exemplifies the Rule of Law to the extent (it is a matter of degree in respect of each item of the list) that (i) its rules are prospective, not retroactive, and (ii) are not in any other way impossible to comply with; that (iii) its rules are promulgated, (iv) clear, and (v) coherent one with another; that (vi) its rules are sufficiently stable to allow people to be guided by their knowledge of the content of the rules; that (vii) the making of decrees and orders applicable to relatively limited situations is guided by rules that are promulgated, clear, stable and relatively general; and that (viii) those people who have authority to make, administrator, and apply the rules in an official capacity (a) are accountable for their compliance with rules applicable to their performance and (b) do actually administer the law consistently and in accordance with its tenor".
} 
Sendo assim, a definição de padrões e generalidade atribuem racionalidade às normas, uma vez que as hipóteses fáticas, contidas na norma, possibilitam o enquadramento dos fatos sociais que possuem relevância maior à ordem jurídica, atribuindo, reitera-se, previsibilidade e calculabilidade no comportamento estatal e nas condutas sociais. Caso os responsáveis pela aplicação do direito deixassem de lado a generalidade das normas, passando a realizar juízos valorativos subjetivos concretos, não se trataria mais de direito racional, uma vez que ausente a previsibilidade (BARZOTTO, 2017, p. 83). O aplicador ou os órgãos jurisdicionais que se ocupam exclusivamente com o direito têm o dever de garantir a concretização da lei, que expressa a forma pela qual se definiram as finalidades a serem buscadas pela sociedade (JHERING, 2002).

O Estado ideal, portanto, é aquele que, em seu âmbito formal, sujeita-se às leis produzidas por alguém que tenha sua legitimidade definida por livre e universal escolha e, no aspecto substancial, que promova e institua suas leis em conformidade com a razoabilidade prática, tendo como finalidade o alcance do bem comum. Sem ambas as convergências, torna-se impossível obter um Estado de Direito pleno (MARTINS, 1983).

Nessa perspectiva, a da garantia da segurança nas relações, por meio da definição de padrões racionais de comportamento, o princípio do Estado de Direito nos leva à necessária organização e definição de funções dos poderes. A separação dos poderes, portanto, decorre da necessária constituição de órgãos estatais com diferentes tarefas, que lhe são atribuídas visando a garantir, dentre outros, a segurança pública, a manutenção da ordem e da paz e a proteção e concretização de direitos e garantias individuais (STARCK, 2005); sendo necessários, ainda, a organização e promoção da unidade política, com a finalidade de desenvolver objetivos direcionados ao bem comum, com serviços de interesse geral, bem como com o planejamento, de forma ativa, de inúmeras áreas da vida (HESSE, 1993, p. 198-199). Isso significa dizer que o princípio da separação dos poderes se trata da expressão, além do Estado do Direito, da limitação do poder estatal, tendo como objetivo garantir a concretização de um Estado Democrático, i.e., o princípio da separação dos poderes está relacionado, também, à ideia de democracia, no sentido de proteger a liberdade e a dignidade dos indivíduos, impondo barreiras ao uso irrestrito e arbitrário dos poderes concedidos ao Estado (STARCK, 2005, p. 81). ${ }^{7}$

Relativamente ao direito brasileiro, o artigo 2ํㅡㄹ da Constituição Federal de 1988 - CF define que "são Poderes da União, independentes e harmônicos entre si, o Legislativo, o Executivo e o Judiciário". Ou seja, a norma em tela retrata os poderes como independentes e harmônicos entre si, deixando claro que sua finalidade é a garantia de uma relação equilibrada e em concordância entre estes, na medida em que almeja um ideal de coexistência funcional entre os poderes (ÁVILA, 2012). Assim, para que se mantenha a estabilidade do sistema, torna-se imprescindível que cada Poder aja dentro de suas funções, respeitando seus limites, não invadindo o campo de atuação dos demais.

\footnotetext{
7 "Mit der Verankerung des Prinzips der Gewaltenteilung in Art. 20. Abs. 2 S. 2 und Art. 1 Abs. 3 GG - in der letztgenannten Vorschrift beschränkt auf die Unterscheidung nach Staatsfunktionen - hat der Verfassungsgeber ein zentrales Element formeller Rechtsstaatlichkeit in den nach Art. 79 Abs. 3 GG änderungsfesten Verfassungskern aufgenommen. Er knüpft dabei an ein staatstheoretisches Model an, welches in der Zeit der Aufklärung entwickelt wurde und die Beseitigung von Staatswillkür und Machtmissbrauch, mithin den Schutz der Menschenwürde und individuellen Freiheit zum Ziel hat".
} 
Mínimo existencial, assistência social e estado de direito - análise de decisão proferida pelo Tribunal Constitucional Federal da Alemanha

Este preceito, além da definição de coordenação do Estado pela divisão entre poderes, estabelece a divisão funcional no exercício do poder estatal mediante diferentes órgãos, sendo que tais órgãos devem exercer suas funções mediante controle, inibição e moderação de forma recíproca (ÁVILA 2010). O princípio em questão estabelece, portanto, a necessidade de coordenação que se funda na legitimidade de cada Poder no exercício de suas atividades, incluindo o dever de respeitar limites, no sentido de não adentrarem no campo de funções de outro dos poderes. O princípio da separação dos poderes se relaciona, desse modo, como sustentado, com o princípio democrático (FABIO, 2006, p. 625-626) e com o princípio do Estado de Direito.

Udo di Fabio (2006, p. 614), ao tratar da separação dos poderes no direito alemão, destaca que esta se trata de uma norma de prudência e de um princípio constitucional fundamental, caracterizando-se como um dever organizacional e um critério institucional. Como princípio jurídico, tem como objetivo se manter como um mecanismo fundamental de garantia eficaz da liberdade, ou seja, a garantia simultânea da unidade e da separação da autoridade pública com permissões e limitações.

$\mathrm{Na}$ Lei Fundamental da Alemanha, o princípio da separação dos poderes está disposto no artigo 20, §2 e §3, encontrando-se logo após a disposição que define a República da Alemanha como um Estado democrático e social (conforme $\S 1$ do artigo 20) (STARCK, 2015). Ou seja, ao tratar da separação dos poderes neste dispositivo, reitera-se, fica claro que este preceito é fundamental à concretização, também, do princípio democrático, sendo que, conforme a terceira disposição da mesma norma, "a legislação é vinculada pela ordem constitucional, ao passo que o Poder Executivo e o Judiciário estão vinculados pela lei e pela justiça”.

Assim, restará caracterizada violação ao princípio no momento em que um dos Poderes ultrapassar o seu núcleo de ação próprio, interferindo na atividade de outro. No que diz respeito à relação entre Judiciário e Legislativo, deve estar devidamente estabelecido que a tarefa do segundo é a instituição de leis e do primeiro, sua interpretação e aplicação. Desse modo, o Judiciário, ao realizar a atividade explicitamente definida, deve respeitar os limites de sua função, no sentido de não atuar como legislador positivo.

Reitera-se, nesse sentido, que a ideia de separação de poderes será importante na análise do caso em tela, principalmente no que diz respeito à devida manutenção das funções dos poderes e a necessária harmonia entre o Poder Legislativo e o Poder Judiciário, uma vez que, ao tratar da garantia de eficácia, por parte do Judiciário, de direitos fundamentais previstos na Constituição, haverá sempre o risco de invasão por parte deste Poder no campo de atividades do legislador.

\subsection{Mínimo existencial como direito fundamental}

A atual noção de um direito fundamental ao mínimo existencial, ou seja, de um direito a um conjunto de prestações estatais que assegure a cada um (a cada pessoa) uma vida condigna, parte da ideia de que qualquer pessoa necessitada, que não tenha condições de, por si só ou com o auxílio de sua família, prover o seu sustento, tem direito ao auxílio por parte do Estado e da sociedade, de modo que o mínimo existencial, nessa perspectiva, guarda alguma relação (mas não se confunde 
integralmente) com a noção de caridade e do combate à pobreza, central para a doutrina social (ou questão social) que passou a se afirmar já ao longo do Século $\mathrm{XIX}^{8}$, muito embora a assistência aos desamparados tenha constado na agenda da Igreja e de algumas políticas oficiais já há bem mais tempo ${ }^{9}$. Convém recordar, ainda, que já na fase inaugural do constitucionalismo moderno, com destaque para a experiência francesa revolucionária, assumiu certa relevância a discussão em torno do reconhecimento de um direito à subsistência, chegando mesmo a se falar em "direitos do homem pobre", na busca do rompimento com uma tradição marcada pela ideia de caridade, que ainda caracterizava os modos dominantes de intervenção social em matéria de pobreza, debate que acabou resultando na inserção, no texto da Constituição Francesa de 1793, de um direito dos necessitados aos socorros públicos, ainda que tal previsão tenha tido um caráter eminentemente simbólico ${ }^{10}$.

De qualquer sorte, independentemente de como a noção de um direito à subsistência e/ou de um correspondente dever do Estado (já que nem sempre se reconheceu um direito subjetivo (exigível pela via judicial) do cidadão em face do Estado) evoluiu ao longo do tempo, tendo sido diversas as experiências em diferentes lugares, o fato é que cada vez mais se firmou o entendimento - inclusive em Estados constitucionais de forte coloração liberal - de que a pobreza e a exclusão social são assuntos de algum modo afetos ao Estado, ainda que por razões nem sempre compartilhadas por todos e em todos os lugares, visto que mesmo no plano da fundamentação filosófica, ou seja, da sua sinergia com alguma teoria de Justiça, são diversas as alternativas que se apresentam ${ }^{11}$. Mesmo na esfera terminológica nem sempre se verifica coincidência, pois ao passo que alguns (como também prevalece no Brasil) preferem utilizar a expressão mínimo existencial, outros falam em mínimos sociais, ou mesmo em um mínimo de subsistência ou um mínimo vital, embora nem sempre tais expressões sejam utilizadas como sinônimas, visto que podem estar associadas a conteúdos mais ou menos distintos, a despeito de alguns elementos em comum, como é o caso, em especial, o reconhecimento de um direito a prestações materiais por parte do Estado.

Sem prejuízo de sua previsão (ainda que com outro rótulo) no plano do direito internacional dos direitos humanos, como é o caso do artigo XXV da Declaração da ONU, de 1948, que atribui a todas as pessoas um direito a um nível de vida suficiente para assegurar a sua saúde, o seu bem-

\footnotetext{
${ }^{8}$ Cf., por todos, ARNAULD, Andreas von. "Das Existenzminimum", in: ARNAULD, Andreas von; MUSIL, Andreas (Ed.). Strukturfragen des Sozialverfassungsrechts, Tübingen: Mohr Siebeck, 2009, p. 253 e ss., apontando para o fato de que na Legislação da Prússia, em 1794, já havia a previsão da obrigação do Estado em cuidar da alimentação e atenção daqueles cidadãos que não conseguiam prover o seu próprio sustento ou mesmo por meio de outros particulares, com base em disposições legais especiais.

${ }^{9}$ V. também TORRES, Ricardo Lobo. O Direito ao Mínimo Existencial, Rio de Janeiro: Renovar, 2008, p. 3 e ss., e, por último, no âmbito da literatura brasileira dedicada especialmente ao tema, NETO, Eurico Bitencourt. $O$ Direito ao Mínimo para uma Existência Condigna, Porto Alegre: Livraria do Advogado, 2010, p. 23 e ss.

${ }^{10}$ Sobre este debate, v., por todos, HERRERA, Carlos Miguel. Les Droits Sociaux, Paris: PUF, 2009, p. 39 e ss.

${ }^{11}$ Cf., por exemplo, as teorizações de John Rawls e Michael Walzer colacionadas e comentadas por BARCELLOS, Ana Paula de. A Eficácia Jurídica dos Princípios Constitucionais, Rio de Janeiro: Renovar, 2002, p. 123 e ss. A respeito das diversas fundamentações de um direito ao mínimo existencial, v., por último, na doutrina brasileira, TORRES, Ricardo Lobo. O Direito ao Mínimo Existencial, op. cit., p. 13-34 e 54-81. Por último, explorando o tema nessa perspectiva, v. WEBER, Thadeu. Ética e Filosofia do Direito. Autonomia e Dignidade da Pessoa Humana, Petrópolis: Vozes, 2013, especialmente p. 205, a partir do pensamento de John Rawls.
} 
Mínimo existencial, assistência social e estado de direito - análise de decisão proferida pelo Tribunal Constitucional Federal da Alemanha

estar e o de sua família, a associação direta e explícita do assim chamado mínimo existencial com a dignidade da pessoa humana encontrou sua primeira afirmação textual, no plano, constitucional, na Constituição da República de Weimar, Alemanha, em 1919, cujo artigo 151 dispunha que a vida econômica deve corresponder aos ditames da Justiça e tem como objetivo assegurar a todos uma existência com dignidade, noção que foi incorporada à tradição constitucional brasileira desde 1934, igualmente no âmbito da ordem econômica e/ou social, de tal sorte que o artigo 170 da CF dispõe que "a ordem econômica, fundada na valorização do trabalho humano e na livre iniciativa, tem por fim assegurar a todos existência digna, conforme os ditames da justiça social...". É preciso lembrar, contudo, que na condição de finalidade ou tarefa cometida ao Estado no âmbito dos princípios objetivos da ordem social e econômica, o mínimo existencial, ou seja, o dever de assegurar a todos uma vida com dignidade, não implicava necessariamente (aliás, como não implica ainda hoje a depender do caso), salvo na medida da legislação infraconstitucional (especialmente no campo da assistência social e da garantia de um salário mínimo, entre outras formas de manifestação), uma posição subjetiva imediatamente exigível pelo indivíduo. A elevação do mínimo existencial à condição de direito fundamental e sua articulação mais forte com a própria dignidade da pessoa humana e outros direitos fundamentais, teve sua primeira importante elaboração dogmática na Alemanha, onde, de resto, obteve também um relativamente precoce reconhecimento jurisprudencial, do qual se dará notícia na sequência.

Com efeito, a despeito de não existirem, em regra, direitos sociais típicos, notadamente de cunho prestacional, expressamente positivados na LF (1949) - excepcionando-se a previsão da proteção da maternidade e dos filhos, bem como a imposição de uma atuação positiva do Estado no campo da compensação de desigualdades fáticas no que diz com a discriminação das mulheres e dos portadores de necessidades especiais (direitos e deveres que para muitos não são considerados propriamente direitos sociais) - a discussão em torno da garantia do mínimo indispensável para uma existência digna ocupou posição destacada não apenas nos trabalhos preparatórios no âmbito do processo constituinte, mas também após a entrada em vigor da LF de 1949, onde foi desenvolvida pela doutrina, mas também no âmbito da práxis legislativa, administrativa e jurisprudencial.

$\mathrm{Na}$ doutrina do Segundo Pós-Guerra, um dos primeiros a sustentar a possibilidade do reconhecimento de um direito subjetivo à garantia positiva dos recursos mínimos para uma existência digna foi o publicista Otto Bachof (1954, p. 42-43), que, já no início da década de 1950, considerou que o princípio da dignidade da pessoa humana (art. $1^{\circ}, \S 1$, da LF) não reclama apenas a garantia da liberdade, mas também um mínimo de segurança social, já que, sem os recursos materiais para uma existência digna, a própria dignidade da pessoa humana ficaria sacrificada. Por esta razão, o direito à vida e integridade corporal (art. $2^{\circ}$, $§ 2$, da LF) não pode ser concebido meramente como proibição de destruição da existência, isto é, como direito de defesa, impondo, ao revés, também uma postura ativa no sentido de garantir a vida. Cerca de um ano depois da paradigmática formulação de Bachof, o Tribunal Federal Administrativo da Alemanha (Bundesverwaltungsgericht), já no primeiro ano de sua existência, reconheceu um direito subjetivo do indivíduo carente a auxílio material por parte do Estado, argumentando, igualmente com base no postulado da dignidade da pessoa humana, direito geral de liberdade e direito à vida, que o indivíduo, na qualidade de pessoa autônoma e responsável, 
deve ser reconhecido como titular de direitos e obrigações, o que implica principalmente a manutenção de suas condições de existência ${ }^{12}$. Ressalte-se que apenas alguns anos depois o legislador acabou regulamentando - em nível infraconstitucional - um direito a prestações no âmbito da assistência social (art. 4ํㅡㄹ inc. I, da Lei Federal sobre Assistência Social [Bundessozialhilfegesetz]).

Por fim, transcorrido um longo período após a referida decisão do Tribunal Administrativo Federal, também o TCF acabou por consagrar o reconhecimento de um direito fundamental à garantia das condições mínimas para uma existência digna. Da argumentação desenvolvida nesta primeira decisão, extrai-se o seguinte trecho: "certamente a assistência aos necessitados integra as obrigações essenciais de um Estado Social. [...] Isto inclui, necessariamente, a assistência social aos concidadãos, que, em virtude de sua precária condição física e mental, encontram-se limitados na sua vida social, não apresentando condições de prover a sua própria subsistência. A comunidade estatal deve assegurar-Ihes pelo menos as condições mínimas para uma existência digna e envidar os esforços necessários para integrar estas pessoas na comunidade, fomentando seu acompanhamento e apoio na família ou por terceiros, bem como criando as indispensáveis instituições assistenciais"13.

Em que pesem algumas modificações no que tange à fundamentação, bem quanto ao objeto da demanda, tal decisão veio a ser chancelada, em sua essência, em outros arestos da Corte Constitucional alemã, resultando no reconhecimento definitivo do status constitucional da garantia estatal do mínimo existencial ${ }^{14}$. Além disso, a doutrina alemã entende que a garantia das condições mínimas para uma existência digna integra o conteúdo essencial do princípio do Estado Social de Direito, constituindo uma de suas principais tarefas e obrigações (ZACHER, 1987, p. 1062 e ss.). Nessa perspectiva, o que se afirma é que o indivíduo deve poder levar uma vida que corresponda às exigências do princípio da dignidade da pessoa humana, razão pela qual o direito à assistência social - considerado, pelo menos na Alemanha, a principal manifestação da garantia do mínimo existencial -

12 Cf. BVerwGE (Coletânea oficial das decisões do Tribunal Administrativo Federal) no 1, p. 159 (161 e ss.), decisão proferida em 24-06-1954.

${ }^{13}$ Cf. tradução livre de trecho extraído da decisão publicada em BVerfGE (Coletânea oficial das decisões do Tribunal Constitucional Federal) no 40, p. 121 (133).

14 Para tanto, v. BVerfGE no 78, p. 104, reiterada em BVerfGE no 82, p. 60 e no 87, 1p. 53. Ressalte-se que nas duas últimas decisões, se tratou da problemática da justiça tributária, reconhecendo-se para o indivíduo e sua família a garantia de que a tributação não poderia incidir sobre os valores mínimos indispensáveis a uma existência digna. Cuidou-se, contudo, não propriamente de um direito a prestações, mas, sim, de limitar a ingerência estatal na esfera existencial, ressaltando-se aqui também uma dimensão defensiva do direito fundamental ao mínimo para uma existência digna. Note-se que o princípio da dignidade humana passa, sob este aspecto, a constituir limite material ao poder de tributar do Estado (sobre tal perspectiva, v., por todos, ÁVILA, Humberto. Sistema Constitucional Tributário, 3a ed., São Paulo: Saraiva, 2008, p. 498 e ss.). No âmbito da jurisprudência mais recente do Tribunal Constitucional da Alemanha, destaca-se especialmente a decisão proferida em 09.02.2010 (objeto de análise no presente artigo), que teve por objeto o exame da constitucionalidade de alentada reforma da legislação social, a polêmica Reforma Hartz-IV, com destaque para os valores pagos a título de seguro desemprego, igualmente afirmando o dever do Estado com a garantia do mínimo existencial e reconhecendo um direito subjetivo individual e indisponível correspondente. Para maiores detalhes, v. entre outros, as anotações ao julgamento de RIXEN, Stephan. Grundsicherung für Arbeitssuchende: Grundrecht auf Existenzminimum, in: Sozialgerichtsbarkeit, n. 04, 2010, p. 240 e ss. 
Mínimo existencial, assistência social e estado de direito - análise de decisão proferida pelo Tribunal Constitucional Federal da Alemanha

alcança o caráter de uma ajuda para a autoajuda (Hilfe zur Selbsthilfe), não tendo por objeto o estabelecimento da dignidade em si mesma, mas a sua proteção e promoção ${ }^{15}$.

Desenvolvendo os aspectos já referidos, a doutrina (mas também a jurisprudência) constitucional da Alemanha passou a sustentar que - e, em princípio, as opiniões convergem neste sentido - a dignidade propriamente dita não é passível de quantificação, mas sim as necessidades individuais que the são correlatas e que devem ser satisfeitas mediante prestações que são quantificáveis (NEUMANN, 1995, p. 428-429). Por outro lado, a necessária fixação, portanto, do valor da prestação assistencial destinada à garantia das condições existenciais mínimas, em que pese sua viabilidade, é, além de condicionada espacial e temporalmente, dependente também do padrão socioeconômico vigente (STARCK, 1976, p. 522; NEUMANN, 1955, p. 428). Não se pode, outrossim, negligenciar a circunstância de que o valor necessário para a garantia das condições mínimas de existência evidentemente estará sujeito a câmbios, não apenas no que diz com a esfera econômica e financeira, mas também no concernente às expectativas e necessidades do momento (BREUER, 1978).

De qualquer modo, tem-se como certo que da vinculação com a dignidade da pessoa humana resulta que a garantia efetiva de uma existência digna (vida com dignidade) abrange mais do que a garantia da mera sobrevivência física (que cobre o assim chamado mínimo vital e guarda relação direta com o direito à vida), situando-se, de resto, além do limite da pobreza absoluta. Sustenta-se, nesse sentido, que se uma vida sem alternativas não corresponde às exigências da dignidade humana, a vida humana não pode ser reduzida à mera existência (NEUMANN, 1995). Registre-se, neste contexto, a lição de Heinrich Scholler, para quem a dignidade da pessoa humana apenas estará assegurada "quando for possível uma existência que permita a plena fruição dos direitos fundamentais, de modo especial, quando seja possível o pleno desenvolvimento da personalidade" $(\text { SCHOLLER, } 1980 \text {, p. } 676)^{16}$. Tal linha de fundamentação, em termos gerais, tem sido privilegiada também no direito constitucional brasileiro, ressalvada especialmente alguma controvérsia em termos de uma fundamentação liberal ou social do mínimo existencial e em relação a problemas que envolvem a determinação do seu conteúdo, já que, não se há de olvidar, da fundamentação diversa do mínimo existencial podem resultar consequências jurídicas distintas, em que pese uma possível convergência no que diz com uma série de aspectos ${ }^{17}$.

\footnotetext{
15 Esta a oportuna formulação de NEUMANN, Volker, "Menschenwürde und Existenzminimum”, in: Neue Zeitschrift für Verwaltungsrecht, 1995, p. 425. Trilhando perspectiva similar, excluindo a ideia de caridade e destacando que "o direito a um mínimo existencial corresponde ao direito à subsistência de que nos fala Pontes de Miranda", v. LEDUR, José Felipe. Direitos Fundamentais Sociais, Efetivação no âmbito da democracia participativa, Porto Alegre: Livraria do Advogado, 2009, p. 109 e ss.

16 "[W]o ein Dasein möglich ist, welches sich grundrechtlich entfalten kann, insbesondere wo die Möglichkeit der Persönlichkeitsentfaltung besteht" (tradução livre).

17 Para além das referidas contribuições de Ricardo Lobo Torres, Ana Paula de Barcellos e Eurico Bitencourt Neto (v. notas de rodapé no 3 e 5, supra), v. SCAFF, Fernando F. "Reserva do Possível, Mínimo Existencial e Direitos Humanos", in: Revista Interesse Público, vol.32, 2005, p. 213 e ss., (aderindo ao conceito e fundamento proposto por Ricardo Lobo Torres), bem como, LEAL, Rogério Gesta. Condições e Possibilidades Eficaciais dos Direitos Fundamentais Sociais, Porto Alegre: livraria do Advogado, 2009, p. 72 e ss, e CORDEIRO, Karine da Silva. Direitos Fundamentais Sociais. Dignidade da Pessoa Humana e Mínimo Existencial - O Papel do Poder Judiciário, Porto Alegre: Livraria do Advogado, 2012, p. 97 e ss. Associando o conceito e o conteúdo do direito ao mínimo existencial a uma teoria das necessidades básicas, mas afinada - em adesão à tradição alemã
} 
Ainda no contexto do debate jurídico-constitucional alemão, é possível constatar a existência (embora não uníssona na esfera doutrinária) de uma distinção importante no concernente ao conteúdo e alcance do próprio mínimo existencial, que tem sido desdobrado num assim designado mínimo fisiológico, que busca assegurar as necessidades de caráter existencial básico e que, de certo modo, representa o conteúdo essencial da garantia do mínimo existencial, e um assim designado mínimo existencial sociocultural, que, para além da proteção básica já referida, objetiva assegurar ao indivíduo um mínimo de inserção - em termos de tendencial igualdade - na vida social, política e cultural ${ }^{18}$. É nessa perspectiva que, no âmbito de sua justificação jurídico-constitucional - há quem diga que enquanto o conteúdo essencial do mínimo existencial encontra-se diretamente fundado no direito à vida e na dignidade da pessoa humana (abrangendo, por exemplo, prestações básicas em termos de alimentação, vestuário, abrigo, saúde ou os meios indispensáveis para a sua satisfação), o assim designado mínimo sociocultural encontra-se fundado no princípio do Estado Social e no princípio da igualdade no que diz com o seu conteúdo material (SORIA, 2005, p. 647648).

Em que pese certa convergência no que diz com uma fundamentação jurídico-constitucional a partir do direito à vida e do princípio da dignidade da pessoa humana, e tomando como exemplo o problema do conteúdo das prestações vinculadas ao mínimo existencial, verifica-se que a doutrina e a jurisprudência alemã partem - de um modo mais cauteloso - da premissa de que existem diversas maneiras de realizar esta obrigação, incumbindo ao legislador a função de dispor sobre a forma da prestação, seu montante, as condições para sua fruição, etc., podendo os tribunais decidir sobre este padrão existencial mínimo, nos casos de omissão ou desvio de finalidade por parte dos órgãos legiferantes ${ }^{19}$.

Relevante, todavia, é a constatação de que a liberdade de conformação do legislador encontra seu limite no momento em que o padrão mínimo para assegurar as condições materiais indispensáveis a uma existência digna não for respeitado, isto é, quando o legislador se mantiver aquém desta fronteira ${ }^{20}$. Tal orientação, de resto, é que aparentemente tem prevalecido na doutrina e

referida - com uma noção mais alargada e compatível com um mínimo existencial que, além da existência física, abarca uma dimensão sociocultural, v., no direito brasileiro, LEIVAS, Paulo Gilberto Cogo. Teoria dos Direitos Fundamentais Sociais, Porto Alegre: Livraria do Advogado, 2006, especialmente p. 123 e ss. Em sentido similar, v., por último, LEAL, Mônia Clarissa Hennig; BOLESINA, luri. "Mínimo existencial versus mínimo vital: uma análise dos limites e possibilidades de atuação do Poder Judiciário na sua garantia e no controle jurisdicional das políticas públicas", in: ALEXY, Robert; BAEZ, Narciso Leandro Xavier; SANDKÜHLER, Hans Jörg; HAHN, Paulo (Org.), Níveis de Efetivação dos Direitos Fundamentais Sociais: um dilema Brasil e Alemanha, Joaçaba: Editora UNOESC, 2013, p. 543 e ss.

${ }^{18}$ Neste sentido, v., em caráter ilustrativo, SORIA, José Martínez. "Das Recht auf Sicherung des Existenzminimums", in: Juristenzeitung, n. 13, 2005, especialmente p.647-48.

19 Esta é a posição de BREUER, Rüdiger. "Grundrechte als Anspruchsnormen", in: Verwaltungsrecht zwischen Freiheit, Teilhabe und Bindung, Festgabe aus Anlass des 25 jährigen Bestehens des Bundesverwaltungsgerichts (FS für das BVerwG), München: CH Beck, 1978, p. 97, assim como, mais recentemente, MOREIRA, Isabel. A solução dos Direitos, Liberdades e Garantias e dos Direitos Econômicos, Sociais e Culturais. Coimbra: Almedina, 2007, p. 143 e ss. Também o Tribunal Federal Constitucional atribui ao legislador a competência precípua de dispor sobre o conteúdo da prestação. Neste sentido, v. BVerfGE 40, 121 (133) e 87, 153 (170-1). Por último, v., no mesmo sentido, a decisão de 09.02.2010.

${ }^{20}$ Cf. o já referido leading case do Tribunal Constitucional Federal (BVerfGE 40, 121 [133]). 
Mínimo existencial, assistência social e estado de direito - análise de decisão proferida pelo Tribunal Constitucional Federal da Alemanha

jurisprudência supranacional e nacional (constitucional) Europeia ${ }^{21}$, e, de algum modo, parece ter sido assumida como substancialmente correta também por expressiva doutrina e jurisprudência sulamericana, como dão conta importantes contribuições oriundas da Argentina $^{22}$ e da Colômbia ${ }^{23}$. Para o caso brasileiro, basta, por ora, lembrar o crescente número de publicações e de decisões jurisdicionais sobre o tema. No plano judicial, o destaque, dado o enfoque do presente texto, fica com o STF, que tem produzido muitas decisões aplicando a noção de um mínimo existencial a vários tipos de situações envolvendo diversos direitos fundamentais ${ }^{24}$.

\section{ANÁLISE DA DECISÃO DO TRIBUNAL CONSTITUCIONAL FEDERAL DA ALEMANHA ACERCA DO BENEFÍCIO SOCIAL DO SEGUNDO LIVRO DO CÓDIGO SOCIAL ALEMÃO (SGB II) E DO 4 ATO PARA SERVIÇOS MODERNOS NO MERCADO DE TRABALHO (HARTZ IV)}

\subsection{Breve descrição do conteúdo da legislação em questão}

Os benefícios previstos nas normas analisadas pelo TCF têm a finalidade de prover as necessidades básicas às pessoas com capacidade empregatícia que estão fora do mercado de trabalho, bem como para pessoas (familiares) que vivem conjuntamente. Ou seja, nos termos da legislação mencionada, estas pessoas recebem um auxílio pecuniário a título de benefício desemprego, e os dependentes, sem capacidade de trabalho, que vivem na mesma casa de família,

\footnotetext{
${ }^{21}$ Ainda que não se trate do reconhecimento de um direito a prestações propriamente dito, o Tribunal Constitucional Espanhol, na Sentença no 113/1989, entendeu que "Es incompatible con la dignidad de la persona el que la efectividad de los derechos patrimoniales se leve al extremo de sacrificar el mínimo vital del deudor, privándole de los medios indispensables para la realización de sus fines personales. Se justifica así, junto a otras consideraciones, la inembargabilidad de bienes y derechos como límite del derecho a la ejecución de las sentencias firmes." (in: LLORENTE, Francisco Rubio (Org.). Derechos Fundamentales y Principios Constitucionales (Doctrina Jurisprudencial), Barcelona: Ed. Ariel, 1995, p. 73). Já admitindo um direito às prestações vinculadas ao mínimo existencial, v. a já citada decisão do Tribunal Constitucional de Portugal, na esteira de jurisprudência anterior, ainda que em princípio tímida e partindo da primazia da concretização pelos órgãos legiferantes.

${ }^{22}$ V. especialmente COURTIS, Christian; ABRAMOVICH, Victor. Los derechos sociales como derechos exigibles, Madrid: Trotta, 2003, apresentando e comentando um expressivo elenco de casos envolvendo os direitos sociais e o mínimo existencial não limitado à experiência da Argentina.

${ }^{23}$ Inventariando e comentando a jurisprudência constitucional da Colômbia, v. ARANGO, Rodolfo; LEMAITRE, Julieta (Dir.). Jurisprudência constitucional sobre el derecho al mínimo vital, in: Estudos Ocasionales CIJUS, Bogotá: Ediciones Uniandes, 2002.

${ }^{24} \mathrm{~V}$. aqui, entre outras (portanto, em caráter meramente ilustrativo) a decisão relatada pelo Ministro Celso de Mello (Agravo Regimental no RE no 271.286-8/RS, publicada no DJU em 24.11.2000), onde restou consignado igualmente em hipótese que versava sobre o fornecimento de medicamentos pelo estado (no caso, paciente portador de HIV) que a saúde é direito público subjetivo não podendo ser reduzido à "promessa constitucional inconsequente". Entre muitos outros julgados que poderiam ser colacionados, v. a paradigmática decisão monocrática do STF proferida na ADPF $n^{\circ} 45$, igualmente da lavra do Ministro Celso de Mello, afirmando embora não tenha havido julgamento do mérito - a dimensão política da jurisdição constitucional e a possibilidade de controle judicial de políticas públicas quando se cuidar especialmente da implementação da garantia do mínimo existencial. Mais recentemente, v. a STA 241/RJ, Rel. Min. Gilmar Mendes, julgada em 10.10.08 (direito à educação, sufragada por decisões posteriores) e STA 175/CE, Rel. Min. Gilmar Mendes, julgada em 17.03.10 (direito à saúde), bem como, por último, pela sua relevância, as decisões sobre o benefício de assistência social (LOAS), julgadas em 18.04.2013 (RE 567.985 - Mato Grosso, Relator Min. Marco Aurélio, Relator do Acórdão, Ministro Gilmar Mendes) e em 18.04.2013 (Reclamação 4.374 - Pernambuco, Relator Ministro Gilmar Mendes).
} 
em particular crianças (menores de 14 anos, e entre 14 e 15 anos), recebem, como subsídio social, um percentual dos benefícios previstos aos adultos ${ }^{25}$.

Assim, o auxílio previsto no Código de Direito Social (Sozialgesetzbuch) tem as seguintes características:

(i) espécie de benefício padrão com a finalidade de assegurar a subsistência e a vida digna dos cidadãos alemães em situação de desemprego (estendido aos estrangeiros, artigo 7 SGB II), conforme determinado nos artigos 20 e 28 do SGB $\|^{26}$; e

(ii) auxílio de cunho financeiro garantindo a acomodação dos cidadãos ativos, com capacidade laborativa, bem como de seus dependentes. Os auxílios são garantidos somente nos casos de insuficiência de recursos por parte dos beneficiados, especialmente no condiz à renda e à propriedade.

Nestes termos, o Livro II do Código Social fixou, como parâmetro, o benefício de €345 para pessoas solteiras que vivem na antiga Westdeutschland, e de $€ 311$ nos novos Estados Federados da Alemanha (Bundesländern). A regra determinava, ainda, que um percentual destes valores seria destinado aos demais dependentes que vivem no mesmo domicílio ${ }^{27}$, com a previsão, também, de

${ }^{25}$ A legislação define como pessoas capazes de trabalho maiores de 15 e antes dos 65 anos de idade:

“Kapitel 2 Anspruchsvoraussetzungen

$\S 7$ Berechtigte

(1) Leistungen nach diesem Buch erhalten Personen, die

1. mindestens 15 Jahre alt sind und das 65 . Lebensjahr noch nicht vollendet haben,

2. erwerbsfähig sind,

3. hilfebedürftig sind und

4. ihren gewöhnlichen Aufenthalt in der Bundesrepublik,

Deutschland haben, (erwerbsfähige Hilfebedürftige). Ausländer haben ihren gewöhnlichen Aufenthalt in der Bundesrepublik Deutschland und erhalten Leistungen nach diesem Buch, wenn die Voraussetzungen nach $\S 8$ Abs. 3 vorliegen; dies gilt nicht für Leistungsberechtigte nach $\S 1$ des Asylbewerberleistungsgesetzes. Aufenthaltsrechtliche Bestimmungen bleiben unberührt".

26 “§ 20: Regelleistung zur Sicherung des Lebensunterhalts

(1) Die Regelleistung zur Sicherung des Lebensunterhalts umfasst insbesondere Ernährung, Kleidung, Körperpflege, Hausrat, Bedarfe des täglichen Lebens sowie in vertretbarem Umfang auch Beziehungen zur Umwelt und eine Teilnahme am kulturellen Leben. Nicht umfasst sind die in $\S 5$ Abs. 2 Satz 2 dieses Buches genannten Leistungen nach dem Zwölften Buch.

(2) Die monatliche Regelleistung beträgt für Personen, die allein stehend oder allein erziehend sind, in den alten Bundesländern einschließlich Berlin (Ost) 345 Euro, in den neuen Bundesländern 331 Euro.

(...)

$\S 28$ Sozialgeld

(1) Nicht erwerbsfähige Angehörige, die mit erwerbsfähigen Hilfebedürftigen in Bedarfsgemeinschaft leben, er haten, soweit sie keinen Anspruch auf Leistungen nach dem Gesetz über eine bedarfsorientierte Grundsicherung im Alter und bei Erwerbsminderung haben oder diese Leistungen zur Sicherung des Lebensunterhalts nicht ausreichen, als Sozialgeld die sich aus $\S 19$ Satz $1 \mathrm{Nr} .1$ ergebenden Leistungen mit folgenden Maßgaben entsprechend: Die Regelleistung beträgt bis zur Vollendung des 14. Lebensjahres 60 vom Hundert und im 15. Lebensjahr 80 vom Hundert der nach $\S 20$ Abs. 2 maßgebenden Regelleistung. Leistungen für Mehrbedarfe nach $\S 21$ Abs. 4 werden auch gezahlt, wenn Eingliederungshilfe nach $\S 49 \mathrm{Abs}$. $1 \mathrm{Nr} .1$ und 2 des Zwölften Buches erbracht wird. § 21 Abs. 4 Satz 2 gilt auch nach Beendigung der in $\S 49$ Abs. 1 Nr. 1 und 2 des Zwölften Buches genannten Maßnahmen". (1501516 (bundestag.de)).

27 “§20 - SGB

(3) Haben zwei Angehörige der Bedarfsgemeinschaft das 18. Lebensjahr vollendet, beträgt die Regelleistung jeweils 90 vom Hundert der Regelleistung nach Absatz 2. Die Regelleistung für sonstige erwerbsfähige Angehörige der Bedarfsgemeinschaft beträgt 80 vom Hundert der Regelleistung nach Absatz 2". 
Mínimo existencial, assistência social e estado de direito - análise de decisão proferida pelo Tribunal Constitucional Federal da Alemanha

uma diferença para pessoas que moram sozinhas e às que dividem a moradia, que, teoricamente, teriam um gasto menor.

Importante destacar que a norma prevista no SGB II, diferentemente das provisões da Lei Federal de Assistência Social (Bundessozialhilfegesetz - BSHG), determinou o pagamento do benefício forma única, não dispondo sobre condições de necessidades especiais ${ }^{28}$. Previu apenas de forma genérica a possibilidade de complementação em casos excepcionais para necessidades especiais ${ }^{29}$. A legislação em apreço passou a ter efeitos no ano de 2005 , por meio da publicação de um decreto - Regelsatzverordnung 2005.

Contudo, na formulação dos critérios de apuração dos valores que seriam destinados aos beneficiários, deixou de levar em consideração despesas com educação, além de reduzir, em relação à legislação anterior, quantia destinada a outras despesas como vestimenta, gastos com moradia etc. As reduções foram justificadas no sentido de que estes custos não previstos estariam abrangidos pela quantia padrão determinada, e que, nos "casos de necessidades especiais, o beneficiário deveria poupar o valor extra acrescido no benefício ${ }^{30}$.

A polêmica que se instaurou, dentre outros pontos, em torno da ampla reforma levada a efeito pela legislação Hartz IV, aqui com destaque para o benefício acima descrito, acabou aportando no TCF da Alemanha, que, no julgamento, analisou a compatibilidade do benefício padrão para adultos e crianças definidos na legislação mencionada, com a LF, mais especificamente, em relação ao artigo $1^{\circ}$, $\S 1$ (que determina a inviolabilidade da dignidade humana, e impõe, ao Estado, o dever de usar seu poder para a sua proteção ${ }^{31}$ ), e ao artigo 20 , § 1, que estabelece o Estado Social e Democrático de Direito. O ponto de partida do exame levado a efeito pelo Tribunal foi a análise dos benefícios previstos no artigo 20 do SGB II à luz do direito e garantia do mínimo existencial, compreendido em sinergia com a dignidade da pessoa humana.

\footnotetext{
${ }^{28}$ Por condições especiais, entendem-se os casos em que a quantia mencionada não é, comprovadamente, suficiente ao sustento de uma vida digna e em conformidade com o mínimo existencial.

29 “§ 73

Hilfe in sonstigen Lebenslagen

Leistungen können auch in sonstigen Lebenslagen erbracht werden, wenn sie den Einsatz öffentlicher Mittel rechtfertigen. Geldleistungen können als Beihilfe oder als Darlehen erbracht werden".

30 BVerfGE - 1/09, parágrafo 60: "Als Ergebnis weist die Begründung des Verordnungsgebers für die alten Länder einschließlich Berlin (Ost) gerundet den Betrag von 345 Euro aus. Dieser Betrag wurde dadurch ermittelt, dass der nach dem vorstehenden Verfahren aus der Einkommens- und Verbrauchsstichprobe 1998 gewonnene Ausgangswert (630,18 DM) entsprechend der Anpassungsregelung des $§ 4$ Regelsatzverordnung aufgrund der Veränderungen des aktuellen Rentenwerts seit dem 1. Juli 1999 fortgeschrieben wurde (vgl. BRDrucks 206/04, S. 13). Der sich daraus ergebende Betrag von 345 Euro wurde auch für die Zeit ab dem 1. Januar 2005 zugrunde gelegt, da im Zeitpunkt der Erstellung des Entwurfs der Regelsatzverordnung 2005 bereits bekannt war, dass aufgrund des Gesetzes über die Aussetzung der Anpassung der Renten zum 1. Juli 2004 (RAAG), das als Art. 2 des Zweiten Gesetzes zur Änderung des Sechsten Buchs Sozialgesetzbuch und anderer Gesetze vom 27. Dezember 2003 ( BGBI I S. 3013 ) verkündet worden war, zum 1. Juli 2004 keine Erhöhung des aktuellen Rentenwertes stattfinden würde".

31 “I. Die Grundrechte

Artikel 1

(1) Die Würde des Menschen ist unantastbar. Sie zu achten und zu schützen ist Verpflichtung aller staatlichen Gewalt. (2) Das Deutsche Volk bekennt sich darum zu unverletzlichen und unveräußerlichen Menschenrechten als Grundlage jeder menschlichen Gemeinschaft, des Friedens und der Gerechtigkeit in der Welt".
} 


\subsection{Fundamentos da Decisão}

Desse modo, o Tribunal Alemão definiu que:

A) A garantia do mínimo existencial é um direito fundamental, considerado como uma dimensão da dignidade da pessoa humana, que deve ser respeitada e protegida, nos termos do artigo 1, $\S 1$ em conjunto com o artigo $20, \S 1$ da LF. Isso assegura, às pessoas com necessidades, condições materiais mínimas indispensáveis à existência e à participação mínima na vida social, política e cultural. Este direito não pode ser objeto de deliberação por parte do Poder Legislativo. Todavia, as necessidades devem ser definidas de forma concreta e devem ser atualizadas regularmente pela legislação. Ademais, o Estado tem o dever não somente de proteção destes direitos, mas também o dever positivo, de prestações que garantam a efetivação de tais direitos, como no caso de desemprego ${ }^{32}$;

B) A legislação deve tratar da orientação acerca dos benefícios a serem pagos, e, em relação às respectivas necessidades concretas e aos meios de se efetivar tais bens ${ }^{33}$, estes não podem ser inferidos diretamente da Constituição ${ }^{34}$, sendo que o legislador tem o dever de defini-los tomando como base as despesas necessárias à existência digna das pessoas ${ }^{35}$. Para tanto, devem utilizar métodos transparentes e apropriados, condizentes com à realidade ${ }^{36}$;

C) As provisões contidas nos artigos 20 e 28 do Sozialgesetzbuch II são incompatíveis com a garantia fundamental à proteção do mínimo existencial ${ }^{37}$. A definição dos montantes padrão do

32 BVerfGE - 1/09, parágrafo 134: “Der Staat muss die Menschenwürde auch positiv schützen (vgl. BVerfGE $107,275<284>; 109,279<310>$ ). Wenn einem Menschen die zur Gewährleistung eines menschenwürdigen Daseins notwendigen materiellen Mittel fehlen, weil er sie weder aus seiner Erwerbstätigkeit noch aus eigenem Vermögen noch durch Zuwendungen Dritter erhalten kann, ist der Staat im Rahmen seines Auftrages zum Schutz der Menschenwürde und in Ausfüllung seines sozialstaatlichen Gestaltungsauftrages verpflichtet, dafür Sorge zu tragen, dass die materiellen Voraussetzungen dafür dem Hilfebedürftigen zur Verfügung stehen". ${ }^{33}$ BVerfGE - 1/09, parágrafo 137: "Der gesetzliche Leistungsanspruch muss so ausgestaltet sein, dass er stets den gesamten existenznotwendigen Bedarf jedes individuellen Grundrechtsträgers deckt (vgl. BVerfGE 87, 153 $<172>$; $91,93<112>$; 99, $246<261>; 120,125<155$ und 166>). Wenn der Gesetzgeber seiner

verfassungsmäßigen Pflicht zur Bestimmung des Existenzminimums nicht hinreichend nachkommt, ist das einfache Recht im Umfang seiner defizitären Gestaltung verfassungswidrig".

${ }^{34}$ BVerfGE 1/09, parágrafo 138.

35 BVerfGE - 1/09, parágrafo 136: “(...) Die verfassungsrechtliche Gewährleistung eines menschenwürdigen Existenzminimums muss durch ein Parlamentsgesetz erfolgen, das einen konkreten Leistungsanspruch des Bürgers gegenüber dem zuständigen Leistungsträger enthält. Dies findet auch in weiteren verfassungsrechtlichen Grundsätzen seine Stütze. Schon aus dem Rechtsstaats- und Demokratieprinzip ergibt sich die Pflicht des Gesetzgebers, die für die Grundrechtsverwirklichung maßgeblichen Regelungen selbst zu treffen (vgl. BVerfGE 108, $282<311>$ m.w.N.). Dies gilt in besonderem Maße, wenn und soweit es um die Sicherung der Menschenwürde und der menschlichen Existenz geht (vgl. BVerfGE 33, $303<337>$; 40, 237 $<249>$ ). Zudem kann sich der von Verfassungs wegen bestehende Gestaltungsspielraum des Parlaments nur im Rahmen eines Gesetzes entfalten und konkretisieren (vgl. BVerfGE 59, $231<263>$ )".

${ }^{36}$ BVerfGE 1/09, parágrafo, 139: “(...) Zur Konkretisierung des Anspruchs hat der Gesetzgeber alle existenznotwendigen Aufwendungen folgerichtig in einem transparenten und sachgerechten Verfahren nach dem tatsächlichen Bedarf, also realitätsgerecht, zu bemessen".

37 BVerfGE - 1/09, parágrafos 132-133: “§ 20 Abs. 2 1. Halbsatz, Abs. 3 Satz 1 SGB II a.F. und § 28 Abs. 1 Satz 3 Nr. 1 1. Alt. SGB II a.F., jeweils in Verbindung mit $\S 20$ Abs. 1 SGB II a.F., sind mit dem Grundrecht auf Gewährleistung eines menschenwürdigen Existenzminimums aus Art. 1 Abs. $1 \mathrm{GG}$ in Verbindung mit dem Sozialstaatsprinzip des Art. 20 Abs. $1 \mathrm{GG}$ unvereinbar. 
Mínimo existencial, assistência social e estado de direito - análise de decisão proferida pelo Tribunal Constitucional Federal da Alemanha

benefício, não obstante não terem atendido de forma clara os requisitos constitucionais no procedimento de apuração, não atendem completamente as necessidades específicas, pois não tratam de casos especiais de forma concreta ${ }^{38}$;

D) Apesar de o Tribunal reconhecer que não tem condições de demonstrar que os valores previstos pelas normas impugnadas do SGB II, como os auxílios de $€ 345$ e de $€ 311$, ou ainda de $€ 207$ (complementares para crianças até 14 anos de idade), são insuficientes à subsistência, ou que não estão de acordo com o mínimo existencial ${ }^{39}$, o problema está na ausência de previsão concreta acerca dos casos de exceção. Não obstante, não restou verificado que o procedimento que resultou na quantificação daqueles valores atendeu os requisitos constitucionais condizentes com os artigos 11 e 20, §1 da LF. O exemplo disso são as reduções injustificáveis, como no caso da eletricidade e da exclusão dos valores referentes ao estudo;

E) Em virtude da declaração da inconstitucionalidade dos referidos dispositivos, o Tribunal destacou que não pode substituir o legislador para definir as formas adequadas de apuração de valores padrões para o benefício, nem como estipular critérios de análise de casos especiais, motivo pelo qual, concedeu um prazo (dezembro de 2010 ${ }^{40}$ para que o legislador preenchesse estas lacunas e corrigisse a legislação, sendo que as pessoas que necessitassem dos benefícios até esta

Das Grundrecht auf Gewährleistung eines menschenwürdigen Existenzminimums ergibt sich aus Art. 1 Abs. 1 GG in Verbindung mit Art. 20 Abs. 1 GG (vgl. BVerfGE 40, $121<133>; 45,187<228>; 82,60<85>; 113,88<108$ f.>; Urteil vom 30. Juni 2009 - 2 BvE 2/08 u.a. -, juris, Rn. 259). Art. 1 Abs. 1 GG begründet diesen Anspruch. Das Sozialstaatsgebot des Art. 20 Abs. $1 \mathrm{GG}$ wiederum erteilt dem Gesetzgeber den Auftrag, jedem ein menschenwürdiges Existenzminimum zu sichern, wobei dem Gesetzgeber ein Gestaltungsspielraum bei den unausweichlichen Wertungen zukommt, die mit der Bestimmung der Höhe des Existenzminimums verbunden sind (vgl. BVerfGE 35, $202\langle 236\rangle ;$ 45, $376<387>$; 100, $271<284>$ ). Dieses Grundrecht aus Art. 1 Abs. $1 \mathrm{GG}$ hat als Gewährleistungsrecht in seiner Verbindung mit Art. 20 Abs. $1 \mathrm{GG}$ neben dem absolut wirkenden Anspruch aus Art. 1 Abs. $1 \mathrm{GG}$ auf Achtung der Würde jedes Einzelnen eigenständige Bedeutung. Es ist dem Grunde nach unverfügbar und muss eingelöst werden, bedarf aber der Konkretisierung und stetigen Aktualisierung durch den Gesetzgeber, der die zu erbringenden Leistungen an dem jeweiligen Entwicklungsstand des Gemeinwesens und den bestehenden Lebensbedingungen auszurichten hat. Dabei steht ihm ein Gestaltungsspielraum zu".

${ }^{38}$ BVerfGE 1/09, parágrafo 138: "Die hierbei erforderlichen Wertungen kommen dem parlamentarischen Gesetzgeber zu. Ihm obliegt es, den Leistungsanspruch in Tatbestand und Rechtsfolge zu konkretisieren". 39 BVerfGE - 1/09, parágrafo 152: "Für den Betrag der Regelleistung von 345 Euro nach $\S 20$ Abs. 21 . Halbsatz SGB II a.F. kann eine evidente Unterschreitung nicht festgestellt werden, weil die Regelleistung zur Sicherung der physischen Seite des Existenzminimums zumindest ausreicht und der Gestaltungsspielraum des Gesetzgebers bei der sozialen Seite des Existenzminimums weiter ist. So kommt beispielsweise eine Untersuchung des Deutschen Vereins für öffentliche und private Fürsorge zu dem Ergebnis, dass die Beträge des § 2 Abs. 2 Regelsatzverordnung für „Nahrungsmittel, Getränke, Tabakwaren“ sowie für „Beherbergungsdienstleistungen, Gaststättenbesuche" die Ernährung eines Alleinstehenden mit Vollkost decken können (vgl. seine Empfehlungen zur Gewährung von Krankenkostzulagen in der Sozialhilfe, 3. Aufl., sub III $2<$ Stand 1. Oktober 2008>) (...)".

40 BVerfGE - 1/09, parágrafo 216: “Der Gesetzgeber hat die Regelleistung in einem verfassungsgemäßen Verfahren bis zum 31. Dezember 2010 neu festzusetzen. Diese Frist muss für die Durchführung eines erneuten Verfahrens zur realitätsgerechten Bemessung der Leistungen zur Sicherung des Existenzminimums angesichts der lebensbestimmenden Bedeutung der Regelung für eine sehr große Zahl von Menschen ausreichen. Falls der Gesetzgeber am Statistikmodell festhält, kann er auf die Ergebnisse der Einkommens- und Verbrauchsstichprobe 2008 zurückgreifen, die nach der Auskunft des Statistischen Bundesamtes im Herbst 2010 vollständig vorliegen werden (...)". 
data não seriam prejudicadas, recebendo os benefícios por meio da análise individual dos casos, com prestações em espécie, mesmo antes da promulgação da nova disposição ${ }^{41}$.

\subsection{Análise e considerações acerca dos fundamentos da decisão}

Passa-se, neste momento, a tecer uma análise da decisão proferida pelo TCF, indicando as questões mais relevantes percebidas dos fundamentos adotados como justificação do posicionamento proferido pela Corte. Serão feitos, ainda, alguns comentários com a finalidade de comparação do entendimento adotado acerca do mínimo existencial, em especial no que diz com a sua efetivação pela jurisdição constitucional, com as praticadas na ordem constitucional brasileira.

A primeira questão que merece destaque na decisão em comento é a importância dada à dignidade da pessoa humana, e a preocupação com a proteção e garantia do mínimo existencial. Em uma comparação, as prescrições sobre direitos fundamentais presentes na LF apresentam um caráter muito mais pragmático em relação aos termos definidos na CF (que traz um Título inteiro definindo de forma detalhada direitos fundamentais de caráter individual ou social). A LF, por sua vez, trata destes direitos de uma forma mais objetiva e sistemática (SARLET, 2012, p. 58) ${ }^{42}$, sem cometer o equívoco que a CF faz, de misturar vários direitos de natureza diversa, principalmente no que diz respeito a direitos objetivos e subjetivos (SARLET, 2015) ${ }^{43}$. Percebe-se, nesse sentido, que o ponto de partida do TCF, ao analisar a questão definida na legislação (SGB II), acerca dos parâmetros de concessão dos benefícios sociais para os cidadãos com necessidades especiais, dentre estes, aqueles que necessitam de emprego, é a correspondência destes parâmetros com as normas definidas nos artigos $1^{\circ}, \S 1$ e $20, \S 1$ da LF.

O mínimo existencial, definido como a garantia mínima de subsistência das pessoas, que demanda tanto uma proteção negativa contra a intervenção do Estado, quanto a garantia positiva

41 BVerfGE - 1/09, parágrafo 220: “Der Gesetzgeber ist ferner verpflichtet, bis spätestens zum 31. Dezember 2010 eine Regelung im Sozialgesetzbuch Zweites Buch zu schaffen, die sicherstellt, dass besonderer Bedarf nach Maßgabe der Ausführungen zu C. IV. gedeckt wird. Die nach § 7 SGB II Leistungsberechtigten, bei denen ein derartiger besonderer Bedarf vorliegt, müssen aber auch vor der Neuregelung die erforderlichen Sach- oder Geldleistungen erhalten".

42 "Quanto ao conteúdo, merece destaque - até mesmo por se tratar de um dos principais aspectos aos quais se deve o prestígio da Lei Fundamental no âmbito do constitucionalismo contemporâneo - a afirmação da dignidade humana e o dever do Estado de considerá-la e protegê-la, seguida de um catálogo de direitos fundamentais bem estruturado, especialmente em torno da mais ampla proteção das liberdades pessoais. Tanto a forma de positivação da dignidade humana, na condição de princípio estruturante acompanhada de um dever expresso de proteção estatal, quanto a proibição sem exceção da pena de morte dão conta do que os autores da Lei Fundamental quiseram colocar o ser humano no centro da ordem estatal (...)".

43 "Analisada à luz do direito constitucional positivo brasileiro, a questão classificatória revela-se como sendo particularmente problemática. Por um lado, verifica-se a dificuldade de se utilizarem os critérios classificatórios mais comuns na doutrina, na medida em que esbarram nas peculiaridades do direito positivo. Além disso, a ausência de sistematicidade e, em muitos casos, a precária técnica legislativa do nosso texto constitucional, não favorecem o trabalho. Nesse sentido, é preciso ter em vista que a Constituição de 1988 abrigou em seu catálogo (e fora deste) direitos fundamentais que exercem, em princípio, todas as funções referidas no item anterior, vinculadas à sua dupla perspectiva objetiva e subjetiva, utilizando-se, para tanto, das mais variadas técnicas de positivação. Assim, por exemplo, é possível perceber que, no âmbito dos direitos sociais (arts. 6으 a $11 \mathrm{da}$ CF), se encontram tanto direitos a prestações, quanto concretizações dos direitos de liberdade e igualdade, com estrutura jurídica diversa". 
Mínimo existencial, assistência social e estado de direito - análise de decisão proferida pelo Tribunal Constitucional Federal da Alemanha

pelas prestações estatais (TORRES, 1989, p. 35), deve ser um dos critérios para verificar se um direito social (saúde, educação, assistência social, dentre outros) deve ter eficácia promovida por parte do Poder Público no caso concreto. Como fortemente sustentado, a garantia do mínimo existencial serve como parâmetro na definição de um núcleo mínimo de exigência de guarida por parte do Poder Público, sendo que estes critérios foram observados na decisão em análise, conforme acima descrito.

Destacou-se na decisão que a exigência da garantia de um estado de bem-estar, nos termos do da LF, impõe ao legislador a tarefa de assegurar, a todos, um nível mínimo de subsistência, digno de um ser humano. Tal exigência, além de estar fundamentada no Art. 1ํ da LF, em conexão com o Art. $20, \S 1$, baseia-se no direito absoluto à dignidade de cada indivíduo, que é indisponível, mas requer sua concretização e constante atualização pelo legislador. Este, por sua vez, "deve orientar os serviços a serem prestados [pelo Estado] para o respectivo nível de desenvolvimento da comunidade e das condições de vida existentes ${ }^{44 "}$. Para tanto, o legislador, inevitavelmente, possui uma margem de discricionariedade em relação às avaliações necessárias ligadas à determinação do montante que seja capaz de satisfazer o nível mínimo, imprescindível à subsistência. Entretanto, apesar de se verificar um certo grau de liberdade ao legislador no exercício desta função, é imprescindível que, ao definir as condições em que estes preceitos serão efetivados, deve-se observar que as políticas estabelecidas precisam atender um mínimo de subsistência por meio de uma garantia uniforme, sob direitos fundamentais, abrangendo "tanto a existência física da pessoa, ou seja, alimentação, vestuário, utensílios domésticos, alojamento, aquecimento, higiene e saúde", quanto "a salvaguarda da possibilidade de cultivar relações interpessoais e de um grau mínimo de participação na vida social, cultural e política, na medida em que, o ser humano, como pessoa, existe, necessariamente, nas relações sociais ${ }^{45}$ ".

Contudo, não obstante a importância destes preceitos, que serviram de base da ratio decidendi da decisão do TCF, faz-necessária a observação de que a invocação de tais valores tem como consequência um rigoroso ônus argumentativo, para que se justifique sua aplicação ao caso. Além do mais, deve-se ter o cuidado para que, na tentativa desenfreada de efetivação de garantias fundamentais, como a em questão, o Judiciário não passe a atuar de forma constante como legislador, em violação ao princípio da separação dos poderes, o que será analisado mais abaixo.

Outro ponto de grande relevância que se observa na decisão da Corte alemã é a confirmação de que as regras jurídicas devem observar, em sua constituição, questões relacionadas à cognoscibilidade, confiabilidade e previsibilidade. Ou seja, nos termos do parágrafo 91 da decisão em apreço, o TCF destacou que o legislador, ao definir as disposições, consideradas inconstitucionais, deixou de observar os padrões constitucionais de justiça sistêmica, clareza de normas, coerência e proibição de arbitrariedade previstos nos artigos $3^{\circ}$, $\S 1$ e 20 , §3 da LF ${ }^{46}$. Resta claramente

\footnotetext{
44 BVerfGE - 01/09, parágrafo 133.

45 BVerfGE - 01/09, parágrafo 135.

46 BverfGE - 01/09, parágrafo 91: "Schließlich verletzten die gesetzlichen Regelungen auch die Verfassungsmaßstäbe der Systemgerechtigkeit, Normenklarheit, Folgerichtigkeit sowie des Willkürverbots aus Art. 3 Abs. 1 GG und Art. 20 Abs. 3 GG. Schon bei der Auswahl der Referenzgruppe habe der Gesetzgeber gegen das Rechtsstaatsprinzip verstoßen, vor allem weil er entgegen seinen eigenen Vorgaben die Haushalte im
} 
demonstrado, na decisão, que o problema estava não somente no conteúdo da norma, mas, também, na falta de clareza dos critérios utilizados para se definir os montantes a título do benefício social, ou, ainda, na ausência de justificativas para a desconsideração de dados empíricos que seriam essenciais na instituição dos critérios quantitativos relacionados aos auxílios em tela. $O$ destaque foi na ausência de métodos transparentes capazes de justificar as previsões acerca do montante direcionado aos beneficiários do auxílio.

Em relação à interpretação constitucional, o Tribunal fez esforços para tentar ficar o máximo possível adstrito ao texto da LF, respeitando, de certa forma, o grau de conformação e discricionariedade característico da atividade do legislador, uma vez que apenas tratou de estabelecer que o conteúdo normativo, no que se refere aos auxílios concedidos nos dispositivos analisados, resultou na definição de quantias econômicas abaixo de um mínimo considerado necessário à subsistência humana, dentro dos padrões econômicos verificados no sistema alemão. Todavia, o Tribunal não estipulou novas condições em substituição às normas em questão, deixando esta tarefa a cargo do legislador. Importante destacar que este âmbito de separação e limitação entre a atuação do Tribunal Constitucional como guardião da Constituição e a discricionariedade e função do legislador é limítrofe, na medida em que, nos termos da maioria das Constituições de Estados democráticos, a função das cortes constitucionais se limita à análise da constitucionalidade ou não da legislação infra, não havendo qualquer disposição acerca da possibilidade da indicação (ou exigência) do que o legislador deveria fazer. Todavia, entende-se que é inevitável que, em alguns momentos, este limite seja ultrapassado, e o Judiciário acabe indicando, como no caso, os requisitos mínimos aos quais o Legislativo deve se guiar.

Ademais, mais uma vez, é evidente o cuidado que o Tribunal teve ao tratar da questão sob o prisma constitucional, traçando sua decisão com base e limites na interpretação. Ao entender que as normas sub judice não estavam em conformidade com os preceitos tratados na LF, o Tribunal alemão deixou explícito que não poderia definir os termos da abrangência (quantitativa) dos benefícios sociais, sendo que se assim o fizesse, estaria invadindo a área de atuação do Poder Legislativo ${ }^{47}$. Nesse sentido, sobre os limites impostos à interpretação constitucional, Konrad Hesse (1993, p. 29) destaca que a interpretação se vincula ao que está posto e, portanto, os limites da interpretação constitucional se estabelecem nos casos em que não há um caráter vinculante da constituição, quando terminam as possibilidades de uma compreensão significativa do texto normativo, ou, ainda, na medida em que uma solução contradiz claramente o texto normativo. O texto constitucional, como limite, é um pressuposto à "função racionalizadora, estabilizadora e limitadora de poder da Constituição" (HESSE, 1993, p. 29), excluindo a possibilidade de ruptura constitucional, no sentido de

Bezug von Sozialhilfe nicht konsequent separiert und die „Dunkelziffer“ derjenigen Personen nicht berücksichtigt habe, die Sozialhilfeleistungen nicht in Anspruch nähmen, obwohl sie einen Anspruch hierauf hätten. Zudem trenne die Verordnung in nicht nachvollziehbarer Weise die Ergebnisse der Einkommens- und Verbrauchsstichprobe in regelsatzrelevante und nicht regelsatzrelevante Teile".

47 BVerfGE - 01/09, parágrafo 138: "Der Umfang dieses Anspruchs kann im Hinblick auf die Arten des Bedarfs und die dafür erforderlichen Mittel jedoch nicht unmittelbar aus der Verfassung abgeleitet werden (...). Er hängt von den gesellschaftlichen Anschauungen über das für ein menschenwürdiges Dasein Erforderliche, der konkreten Lebenssituation des Hilfebedürftigen sowie den jeweiligen wirtschaftlichen und technischen Gegebenheiten ab und ist danach vom Gesetzgeber konkret zu bestimmen". 
Mínimo existencial, assistência social e estado de direito - análise de decisão proferida pelo Tribunal Constitucional Federal da Alemanha

desvio do texto em casos individuais, bem como a alteração constitucional através da interpretação. Assim, enfatiza o autor que, quando o intérprete desconsidera a constituição, ele não interpreta mais, mas muda ou rompe a constituição. Ambas as situações, de desvio na interpretação constitucional, são excluídas do direito válido (HESSE, 1993).

Neste contexto, como consabido, termos como "dignidade da pessoa humana", "mínimo existencial" ou ainda "proporcionalidade" (como ideia de ponderação de princípios ou regras), comumente utilizados pelos Tribunais Constitucionais em suas fundamentações, apresentam um conteúdo muito abstrato e podem resultar em interpretações que ultrapassam ou rompam com o texto constitucional.

Especificamente em relação às noções de ponderação ou balanceamento (terminologias utilizadas na tradição alemã - Abwägung - e anglo-americana - balancing), José Gomes Canotilho bem aponta que estas são utilizadas sempre nas situações em que há a necessidade se "encontrar o direito" para resolver "casos de tensão", mais especificamente no que diz respeito à colisão entre bens juridicamente protegidos (SARLET, 2012, p. 222-223). A interpretação constitucional tem cada vez mais apresentado este tipo de situação, chegando-se ao ponto de se designar, de forma crítica, que o Estado constitucional contemporâneo se caracteriza como um "Estado de ponderação" (Abwägungsstaat). Normalmente, a ideia de ponderação é vinculada à colisão de direitos fundamentais, surgindo como forma de resolução dos casos nos quais a aplicação do direito pela técnica da subsunção se mostra insuficiente. Todavia, a utilização da assim chamada ponderação ou balanceamento (expressões utilizadas, aqui, como sinônimas) não será necessária em todo e qualquer caso, na medida em que o recurso a tal técnica de aplicação do direito deve ser realizado de forma comedida e mediante $o$ atendimento de determinados critérios, bem como demanda adequada fundamentação capaz de justificar seu uso (SARLET, 2012).

Portanto, a utilização tanto da ponderação, quanto dos termos acima referidos ("dignidade da pessoa humana", "mínimo existencial" e "proporcionalidade") deve vir acompanhada de uma fundamentação consistente, capaz de identificar os conceitos existentes dentro destas disposições, sob o risco de sua utilização indevida. Se cada julgador for utilizar a "interpretação constitucional" ou a "interpretação sistemática da constituição" para invocar o mínimo existencial, no sentido de definir os termos e as quantias nas quais este será plenamente preenchido (o que é tarefa do legislador), o resultado seria o caos e a insegurança jurídica incontrolável. Ou seja, em muitos casos, a dignidade da pessoa humana é utilizada de forma inflacionada e sem o devido rigor argumentativo. Não obstante existirem direitos fundamentais que não são, necessariamente, fundados no conteúdo de dignidade, aqueles que o são (como no caso do mínimo existencial), para que sejam aplicados, devem vir acompanhados de fundamentação suficiente a justificar sua concretização, principalmente no que se refere aos deveres prestacionais.

Em comparação, o Supremo Tribunal Federal do Brasil - STF, por muitas vezes, invoca tais termos sem respeitar o ônus argumentativo ${ }^{48}$, pondo em risco a sua utilização quando realmente necessária. O TCF, no caso estudado, tratou de fundamentar de forma pormenorizada suas razões e justificações para a invocação dos princípios constitucionais da proteção da dignidade humana e do

${ }^{48}$ Cf., por exemplo, ADI 4.638/DF. 
mínimo existencial e, mesmo assim, limitou-se a declarar a inconstitucionalidade das normas, sem invadir o campo do Legislativo, no sentido de criar comandos normativos inexistentes no direito vigente. Isso demonstra o respeito à divisão dos poderes e ao sistema como um todo, mantendo-se a coerência necessária ao bom andamento de um Estado de Direito. Ao determinar que fossem providenciados os devidos ajustes na legislação, em conformidade com o texto constitucional, a opção tomada foi por preservar a função do Legislativo como responsável pela definição dos critérios de concretização dos direitos fundamentais em tela.

Dessa forma, o Tribunal alemão, ao considerar que as normas objeto do julgamento não observaram os critérios constitucionais na sua instituição, reservou a limitação que the é imposta em virtude de sua competência, determinando que o legislador providenciasse as correções necessárias. Como órgão que tem a função de guardião da constituição e protetor dos direitos e garantias fundamentais, considerou que o legislador foi insuficiente na elaboração da legislação que previu benefícios sociais às pessoas desempregadas e seus dependentes, porém, não adotou a posição de legislador positivo.

Assim, determinou que o legislador, dentro de um prazo estipulado pela própria Corte, providencia-se a reformulação das regras consideradas insuficientes do ponto de vista constitucional. Nesse sentido, Konrad Hesse destaca que, na moldura das funções a serem desempenadas por cada Poder, são atribuídos, a cada órgão específico, âmbitos de tarefas determinados e limitados (HESSE, 1993, p. 199-200). Os limites podem decorrer de transcrições positivas, com a atribuição das respectivas competências; podem ser resultado, também, de competências negativas, ou, ainda, da proibição expressa da ingerência em uma função alheia (HESSE, 1993, p. 200). Isto quer dizer que as funções e limitações atribuídas aos poderes tornam a construção estatal visível e transparente, na medida em que criam clareza na responsabilidade e produzem um efeito racionalizador (HESSE, 1993, p. 200-201).

Nesse sentido, foi destacado na decisão que, do ponto de vista constitucional, o Tribunal Social Federal (Bundessozialgericht) manteve sua convicção no sentido de que, no caso do auxílio previsto na SGB para solteiros, o valor de $€ 345$ estaria dentro da margem de conformação na atuação do legislador, uma vez que não há como quantificar com precisão o direito a ser concedido de acordo com nível mínimo de subsistência derivado do artigo $1^{\circ}$ em conjunção com o artigo 20 da LF, diferentemente do que ocorre no caso do benefício concedido às crianças, sendo que, além de não restar devidamente demonstrado o porquê das reduções realizadas, não ficou claro se o legislador considerou ou não custos básicos como educação, vestimenta, dentre outros. Não obstante, o legislador, na definição das quantias em discussão, utilizou-se de levantamento de dados cujo próprio instituto que realizou esta pesquisa apontou, expressamente, que os valores indicados não poderiam servir de base ou não poderiam ser equiparados ao custo de vida das crianças. Não restou claramente demonstrado, desse modo, quais foram os critérios adotado para se chegar à quantia de $€ 207^{49}$.

Conforme destaca Udo di Fabio (2006, p. 632-635), a jurisdição constitucional ocupa uma posição especial no conjunto da separação de poderes, sobretudo porque cumpre o dever de garantir

49 BVerfGE - 01/09, parágrafos 100 e 101. 
Mínimo existencial, assistência social e estado de direito - análise de decisão proferida pelo Tribunal Constitucional Federal da Alemanha

que o legislador, no exercício de suas funções, observe da ordem constitucional, podendo, desse modo, declarar leis inconstitucionais e, portanto, regularmente nulas (conforme artigo 100, §1 da LF). Os direitos fundamentais são valores positivados e que representam a vontade do povo, na medida em que decorrente da deliberação de legisladores (constituintes) eleitos democraticamente. Desse modo, é papel do Judiciário, também, garantir a eficácia destas garantias, mesmo que, para isso, seja necessária a anulação de leis que vão de encontro aos preceitos constitucionais fundamentais (MÖLLERS, 2008, p. 143).

Entretanto, isso não pode ser motivo de abusos e de desrespeito a outros preceitos previstos de forma explícita na LF. Ao exercer seu papel de guardião da constituição, o Tribunal Constitucional não pode ignorar por completo a organização do Estado e a necessária manutenção do Estado de Direito, respeitando os limites na sua função, no sentido de não invadir o campo dos demais poderes e, neste caso, evitando que suas decisões resultem na definição positiva de novos termos legislativos (MÖLLERS, 2008, p. 145). Como visto acima, o Tribunal reconheceu a existência de uma "moldura" na qual o legislador exerce seu poder discricionário, mas tratou de definir que existem certos limites que devem ser respeitados de acordo com os valores e princípios constitucionais. Desse modo, mais uma vez, o Tribunal Alemão, ao se resguardar em virtude da sua função, foi capaz de tornar eficaz direitos e garantias fundamentais mantendo a ordem da organização constitucional acerca da divisão dos poderes.

\section{CONSIDERAÇÕES FINAIS}

À vista do exposto, o que se pode constatar é que - diferentemente do em geral ocorre, por exemplo, no caso brasileiro - o TCF logrou, na decisão aqui apresentada e comentada, seguindo também, salvo exceções bem pontuadas, a sua trajetória anterior, reconhecer a ilegitimidade constitucional de aspectos da legislação HARZ IV, sem, contudo, intervir, de modo excessivo, na esfera de atuação do legislador democraticamente legitimado, respeitando substancialmente a sua necessária liberdade de conformação e sem extrapolar, ademais disso, os limites da interpretação constitucional, preservando de tal sorte a higidez do princípio da separação dos poderes, um dos esteios do Estado Democrático de Direito.

Note-se, ainda, que o TCF, embora reconhecendo a inconstitucionalidade sem a correspondente pronúncia de nulidade e remetendo ao legislador a tarefa de corrigir os aspectos tidos como constitucionalmente ilegítimos, deixou assentado que, tratando-se de um direito fundamental e, em especial, do mínimo existencial, onde está em causa a dignidade da pessoa humana, a decisão final sobre eventual violação de tal direito segue sendo sua, dada a vinculação de todos os atores estatais aos direitos fundamentais, ademais dos seus correspondentes deveres de proteção, que, no caso da dignidade humana, encontram-se expressamente estabelecidos no artigo $1^{\circ} \mathrm{da}$ LF. 
Outro aspecto a ser destacado e que merece particular atenção, é o fato de que o TCF, levando em conta as exigências do princípio do Estado de Direito, incluiu na sua fundamentação, o fato de que o legislador não demonstrou, de modo transparente e acessível ao cidadão, quais os critérios que motivaram as suas opções que levaram às reformas levadas a efeito, que, dentre outros pontos, reduziram valores de benefícios sociais.

Com isso, além de respeitar, num exercício de autocontenção (self restraint), os espaços do legislador democraticamente legitimado e os limites da interpretação constitucional, o TCF também destacou a necessária atenção ao dever de coerência (no sentido da concretude e cognoscibilidade), bem como da integridade e previsibilidade da legislação, igualmente exigências nucleares da concepção de Estado de Direito adotada pela LF e desenvolvida pelo próprio Tribunal ao longo de sua judicatura.

\section{REFERÊNCIAS}

ARANGO, Rodolfo; LEMAITRE, Julieta (Dir.). Jurisprudência constitucional sobre el derecho al mínimo vital, in: Estudos Ocasionales CIJUS, Bogotá: Ediciones Uniandes, 2002.

ARNAULD, Andreas von. "Das Existenzminimum", in: ARNAULD, Andreas von; MUSIL, Andreas (Ed.). Strukturfragen des Sozialverfassungsrechts, Tübingen: Mohr Siebeck, 2009.

ÁVILA, Humberto. A Separação dos Poderes e as Leis Interpretativas Modificativas de Jurisprudência Consolidada. In DERZI, Misabel Abreu Machado (Coordenadora). Separação dos Poderes e Efetividade do Sistema Tributário. Belo Horizonte: Del Rey, 2010.

ÁVILA, Humberto. Sistema Constitucional Tributário, 3aㅡ ed., São Paulo: Saraiva, 2008.

ÁVILA, Humberto. Sistema Constitucional Tributário. 5르 Ed. Saraiva: São Paulo, 2012.

BACHOF, Otto. "Begriff und Wesen des sozialen Rechtsstaates", in: Veröffentlichungen der Vereinigung der deutschen Staatsrechtslehrer, no 12, 1954.

BARCELLOS, Ana Paula de. A Eficácia Jurídica dos Princípios Constitucionais, Rio de Janeiro: Renovar, 2002.

BARZOTTO, Luiz Fernando. Teoria do Direito. Porto Alegre: Livraria do Advogado, 2017.

BREUER, Rüdiger. "Grundrechte als Anspruchsnormen", in: Verwaltungsrecht zwischen Freiheit, Teilhabe und Bindung, Festgabe aus Anlass des 25 jährigen Bestehens des Bundesverwaltungsgerichts (FS für das BVerwG), München: $\mathrm{CH}$ Beck, 1978. 
Mínimo existencial, assistência social e estado de direito - análise de decisão proferida pelo Tribunal Constitucional Federal da Alemanha

CARRAZZA, Roque Antônio. Curso de Direito Tributário Constitucional. 29ª ed., revista, ampliada e atualizada até a Emenda Constitucional n. 72/2013. Malheiros: São Paulo, 2013.

CORDEIRO, Karine da Silva. Direitos Fundamentais Sociais. Dignidade da Pessoa Humana e Mínimo Existencial - O Papel do Poder Judiciário, Porto Alegre: Livraria do Advogado, 2012.

COURTIS, Christian; ABRAMOVICH, Victor. Los derechos sociales como derechos exigibles, Madrid: Trotta, 2003.

FINNIS, John. Natural Law and Natural Rights. 2ํe ed. New York: Oxford University Press, 2011.

HESSE, Konrad. Elementos de Direito Constitucional da República Federal da Alemanha. Tradução da $20^{\underline{a}}$ ed. De Luís Afonso Heck. Porto Alegre: Sérgio Antonio Fabris, 1998.

HESSE, Konrad. Grundzüge des Verfassungsrechts der Bundesrepublik Deutschland. 19. ed., Heidelberg: Müller Jur., 1993.

HERRERA, Carlos Miguel. Les Droits Sociaux, Paris: PUF, 2009.

JHERING, Rudolf von. A Finalidade do Direito. Tomo I. Tradução: Heder K. Hoffmann. Campinas/SP: Bookseller, 2002.

KRONBAUER, Eduardo Luís. Fundamentação das Normas Extrafiscais na Perspectiva do Direito Natural. Curitiba: Instituto Memória, 2019.

LEAL, Mônia Clarissa Hennig; BOLESINA, luri. "Mínimo existencial versus mínimo vital: uma análise dos limites e possibilidades de atuação do Poder Judiciário na sua garantia e no controle jurisdicional das políticas públicas", in: ALEXY, Robert; BAEZ, Narciso Leandro Xavier; SANDKÜHLER, Hans Jörg; HAHN, Paulo (Org.), Níveis de Efetivação dos Direitos Fundamentais Sociais: um dilema Brasil e Alemanha, Joaçaba: Editora UNOESC, 2013.

LEAL, Rogério Gesta. Condições e Possibilidades Eficaciais dos Direitos Fundamentais Sociais, Porto Alegre: livraria do Advogado, 2009.

LEDUR, José Felipe. Direitos Fundamentais Sociais, Efetivação no âmbito da democracia participativa, Porto Alegre: Livraria do Advogado, 2009.

LEIVAS, Paulo Gilberto Cogo. Teoria dos Direitos Fundamentais Sociais, Porto Alegre: Livraria do Advogado, 2006. 
LLORENTE, Francisco Rubio (Org.). Derechos Fundamentales y Principios Constitucionales (Doctrina Jurisprudencial), Barcelona: Ed. Ariel, 1995.

MARTINS, Ives Gandra da Silva. Teoria da Imposição Tributária. Saraiva: São Paulo, 1983.

MÖLLERS, Christoph. Die drei Gewalten: Legitimation der Gewaltengliederung in Verfassungsstaat, Europäischer Integration und Internationalisierung. Göttingen: Hubert, 2008.

MOREIRA, Isabel. A solução dos Direitos, Liberdades e Garantias e dos Direitos Econômicos, Sociais e Culturais. Coimbra: Almedina, 2007.

NETO, Eurico Bitencourt. O Direito ao Mínimo para uma Existência Condigna, Porto Alegre: Livraria do Advogado, 2010.

NEUMANN, Volker, "Menschenwürde und Existenzminimum", in: Neue Zeitschrift für Verwaltungsrecht, 1995.

RIXEN, Stephan. Grundsicherung für Arbeitssuchende: Grundrecht auf Existenzminimum, in: Sozialgerichtsbarkeit, n. 04, 2010.

SARLET, Ingo Wolfgang. A Constituição em Perspectiva Histórico-Evolutiva: dos antecedentes à afirmação do constitucionalismo moderno e do assim chamado Estado Constitucional. In: SARLET, Ingo Wolfgang; MARINONI, Luiz Guilherme; MITIDIERO, Daniel. Curso de Direito Constitucional. 2. ed. Porto Alegre: Revista dos Tribunais, 2012.

SARLET, Ingo Wolfgang. A Eficácia dos Direitos Fundamentais. 12ª ed., Porto Alegre: Livraria do Advogado, 2009.

SARLET, Ingo Wolfgang. Linhas Mestras da Interpretação Constitucional. In: MARINONI, Luiz Guilherme; MITIDIERO, Daniel. Curso de Direito Constitucional. 2. ed. Porto Alegre: Revista dos Tribunais, 2012.

SCHOLLER, Heinrich. "Die Störung des Urlaubsgenusses eines 'empfindsamen Menschen' durch einen Behinderten", in: Juristenzeitung, 1980

SCHWABE, Jurgen. Cinquenta anos de jurisprudência do Tribunal Constitucional Alemão. Organização e tradução: Leonardo Martins. Montevideo: Konrad Adanauer, 2005.

SORIA, José Martínez. "Das Recht auf Sicherung des Existenzminimums", in: Juristenzeitung, n. 13, 2005. 
Mínimo existencial, assistência social e estado de direito - análise de decisão proferida pelo Tribunal Constitucional Federal da Alemanha

STARCK, Christian (org.). Kommentar zum Grundgesetz. º vol. München: Franz Vahlen, 2005.

STARCK, Christian. "Staatliche Organisation und Staatliche Finanzierung als Hilfen zur Grundrechtsverwirklichungen?", in: STARCK, Christian (Org). Bundesverfassungsgericht und Grundgesetz, Festgabe aus Anla des 25 jëhrigen Bestehens des Bundesverfassungsrerichts, vol. II (BVerfG und GG II), Tübingen: J. C. Mohr (Paul Siebeck), 1976.

TORRES, Ricardo Lobo. O Direito ao Mínimo Existencial, Rio de Janeiro: Renovar, 2008.

TORRES, Ricardo Lobo. O mínimo existencial e os direitos fundamentais. Revista de Direito Administrativo. Rio de Janeiro: jul/set 1989.

ZACHER, Hans-Friedrich. "Das soziale Staatsziel", in: Isensee-Kirchhof (Org.). Handbuch des Staatsrechts der Bundesrepublik Deutschland (HBStR), vol. I, Heidelberg, CF Muller, 1987.

WEBER, Thadeu. Ética e Filosofia do Direito. Autonomia e Dignidade da Pessoa Humana, Petrópolis: Vozes, 2013. 